\title{
Mismatches between legislative frameworks and benefits restrict the implementation of the Ecosystem Approach in coastal environments
}

\author{
Alison R. Holt ${ }^{1, *}$, Jasmin A. Godbold ${ }^{2}$, Piran C. L. White ${ }^{3}$, Anne-Michelle Slater ${ }^{4}$, \\ Eduardo G. Pereira ${ }^{4}$, Martin Solan ${ }^{2}$
}

\author{
${ }^{1}$ Department of Animal and Plant Sciences, University of Sheffield, Sheffield S10 2TN, UK \\ ${ }^{2}$ Oceanlab, University of Aberdeen, Main Street, Newburgh, Aberdeenshire AB41 6AA, UK \\ ${ }^{3}$ Environment Department, University of York, Heslington, York YO10 5DD, UK \\ ${ }^{4}$ School of Law, Taylor Building, University of Aberdeen, Aberdeen AB24 3UB, UK
}

\begin{abstract}
The Ecosystem Approach is increasingly being adopted as a framework for developing environmental policy because it forms a strategy for the management and sustainable use of land, water and living resources. Yet it is not clear how this approach translates into policies that will create the integrated management necessary to protect the environment and supply the benefits which society values. Here we explore the disconnect between current policy and legislation aiming to conserve and protect specific components of coastal wetland ecosystems, and the aspirations of the Ecosystem Approach. Using an estuarine case study, we illustrate the benefits that people value from coastal wetlands and evaluate the extent to which current institutional arrangements protect these benefits. We find that cultural services are the most valued, particularly recreational activities and the enhancement of human wellbeing through a sense of belonging. Although many laws exist that relate to different components of coastal wetland areas, a diversity of organisations are responsible for their implementation, and they do not always adequately protect the benefits most valued by people. In order to successfully move towards the implementation of an Ecosystem Approach, we argue that new institutional arrangements are required. These need to encompass formal laws that protect those ecosystem processes and functions that are necessary to support valued benefits, whilst recognising the need for bridging and coordinating networks of organisations for the integrated management of coastal wetlands.
\end{abstract}

KEY WORDS: Coastal wetlands - Ecosystem services - Network - Ecosystem management · Recreation · Human well-being

\section{INTRODUCTION}

The Ecosystem Approach is increasingly being adopted at an international and national level as a framework for environmental policy development which aims to maintain the benefits that humans derive from ecosystems, whilst minimising any environmental externalities arising from the use of these benefits or the processes that people use to generate them. Its importance was emphasised in the Millennium Ecosystem Assessment (MA 2005), and its principles underpin recent policy developments such as the
European Water Framework Directive (2000/60/EC) and the Marine Strategy Framework Directive (2008/ 56/EC) (EUR-Lex 2010a,b). The ecological concept behind these directives is intuitive, as it recognises the interdependencies of abiotic and biotic components in delivering ecosystem services in natural systems. However, the translation of the directives into practical monitoring and hypothesis-driven research has been challenging (Basset 2010, Borja et al. 2010, Van Hoey et al. 2010), and questions have been raised about the availability of sufficient and appropriate data in marine systems to underpin decision making (Reiss et al. 2010, 
Atkins et al. 2011, Heymans et al. 2011). Nevertheless, regional management measures that are explicitly based on the Ecosystem Approach have been adopted including, e.g. the Helsinki Commission Baltic Sea Action Plan (Backer et al. 2010) and A Land Use Strategy for Scotland (Scottish Government 2011a). Both of these strategies take an anthropocentric viewpoint (Yaffee 1999), as they involve the integrated management of land, water and living resources, promote conservation and sustainable use in an equitable way, and recognise that people with their cultural and varied social needs are an integral part of ecosystems. Whilst the Malawi principles which underlie the Ecosystem Approach (Convention on Biological Diversity: www. cbd.int/) advocate that the management objectives should be a matter of societal choice, the Ecosystem Approach also emphasises the importance of a healthy environment in underpinning human benefits and wellbeing through the sustained provision of ecosystem services (MA 2005, Dasgupta 2010). These ecosystem services are in turn dependent on functions and processes occurring in the ecosystem as a result of interactions between biodiversity and the physical and chemical environment (White et al. 2010).

Some benefits that humans derive from ecosystems are direct economic ones, such as the production of food or timber, but the environment can also provide opportunities for recreation and for cultural and spiritual wellbeing (MA 2005, UKNEA 2011). For example, catchments, river basins, wetlands and other water sources often form the foundation for cultural or community identity and sense of place (Parkes \& Panelli 2001, Everard et al. 2010). Increasingly, it is recognised that the environment may play a significant role in enhancing human health and wellbeing, both mental and physical (Barton \& Pretty 2010, Lloret 2010, Thompson Coon et al. 2011). In addition, a healthy environment is vital for buffering human health and wellbeing from extreme climate events that are likely to increase in the future as a result of climate change (Tong et al. 2010). The challenge of the Ecosystem Approach is to find ways in which we can manage the physical and biological components of the ecosystem as a whole to maximise these diverse benefits, and at the same time minimise conflicts between the different sectors of the human population who benefit from them (White et al. 2010). Finding solutions to this challenge requires an improved understanding of the science underpinning the links between biodiversity and ecosystem services, as well as of the preferences and motivations of society for the benefits the ecosystem provides.

This ecosystem-based understanding of which components contribute to benefits is at odds with much current environmental policy and legislation, which tends to be focused on specific ecosystem components.
For example, within the UK, the conservation of biodiversity is governed by EU Council Directive 92/43/EEC. This focuses on the conservation of threatened habitats and wild species and has been implemented through the designation of specific protected sites, including Sites of Special Scientific Interest (SSSI), Special Areas of Conservation (SAC) and Special Protection Areas (SPA). Certain species- and habitat-specific conservation programmes have been introduced as a UK Biodiversity Action Plan (BAP) in response to the Convention on Biological Diversity (CBD) which emerged from the 1992 Rio Earth Summit. Currently, the UK BAP extends to 1150 species and 65 habitats (Natural England, www.naturalengland.org.uk/ourwork/conservation/ biodiversity/protectandmanage/ukactionplan.aspx). In addition, initiatives have been established to reduce the adverse impacts on biodiversity associated with specific agricultural or fisheries practices in certain areas and to encourage the adoption of more environmentally-benign production methods. Examples include the designation of Nitrate Vulnerable Zones (NVZs) and Environmentally Sensitive Areas (ESAs), or the adoption of more benign fishing gears (Jennings \& Revill 2007). These existing controls therefore operate either on specific areas or on the organisms that inhabit and move through them. Hence, the legislative framework focuses on specific components of the ecosystem, rather than on the contribution that ecosystems as a whole make to human benefits.

More recently, legislation has moved towards a more system-level focus. The European Water Framework Directive (WFD; 2000/60/EC) marks a change in emphasis, part of the so called third wave of EU legislation which adopts a holistic approach to environmental protection and regulation. It sets out requirements for water resource management across the EU. In particular, it requires the introduction of a comprehensive regime of river basin management planning within a strict timetable, in order to bring water quality to a 'good' standard, as defined in the WFD. It has the objective of achieving 'good ecological status' in all aspects of these waters and the surrounding environment, based on the implicit principle that achieving ecological health will bring broader benefits to society (Moran \& Dann 2008). The European Marine Strategy Framework Directive (MSFD; 2008/56/EC) and the associated Marine and Coastal Access Act 2009 and the Marine (Scotland) Act 2010 in the UK take a similarly broad perspective for maintaining healthy ecosystems in marine waters. The WFD and the MSFD take rather different approaches to implementing the Ecosystem Approach (Borja et al. 2010), but both share a focus on the status of various non-human components of the ecosystem (WFD: biological, chemical and morphological conditions associated with no or very low 
human pressure; MSFD: qualitative descriptors include, e.g. elements of marine food webs, biological diversity, hydrographical conditions and sea floor integrity), which conflicts with the focus of the Ecosystem Approach on human benefits. Moreover, the implementation of these directives by policy makers has so far been rather piecemeal and has failed to meet the more holistic aspirations of the original legislation (Moss 2008, Wakefield 2010). This gap has recently been recognised, in terms of policy development, in the terrestrial environment by the publication of a Land Use Strategy for Scotland (Scottish Government 2011a). For example, Proposal 8 states 'Demonstrate how the Ecosystem Approach could be taken into account in relevant decisions made by public bodies to deliver wider benefits, and provide practical guidance' (p. 20) and Proposal 10 is to 'Investigate the relationship between land management changes and ecosystem processes to identify adaptation priorities' (p. 21). The implementation of this is at an early stage; however, this contribution should inform development of both guidance and practical application of the Ecosystem Approach in marine systems (Scottish Government 2011b).

To effectively implement the Ecosystem Approach, it is important to understand the significance of the disconnect between the current system of environmental conservation policy and the aims of the Ecosystem Approach, both in terms of environmental protection but also in relation to human benefits (Berkes 2010, Ecke et al. 2010). Such an analysis can inform the future development of environmental policy based on an Ecosystem Approach, by identifying key gaps or inconsistencies in coverage and considering ways in which these can be addressed. In addition, because the focus of the Ecosystem Approach is on human benefits, it is important to include the perceptions of human stakeholders in any analysis, especially concerning the nature of the benefits derived and any potential conflicts between them, which could act as a constraint on future policy initiatives. Here, we use the Ythan Estuary in Aberdeenshire, Scotland, as a case study to consider the implementation of an Ecosystem Approach to management.

The Ythan catchment is $\sim 640 \mathrm{~km}^{2}$ in area and drains a low-altitude watershed (maximum elevation $200 \mathrm{~m}$ ) in Aberdeenshire, north-east Scotland (Wiegand et al. 2010). Land use within the catchment is dominated by arable agriculture (>90\%, barley, wheat and oil seed rape), and it also supports large numbers of cattle and pigs (Raffaelli 1999). Land within the catchment area is predominantly owned by individual farmers and larger estates in rural areas and is affected by a number of legislative instruments. Farm incomes are enhanced through compliance with various agri- environment schemes, including voluntary agreements and community involvement (Morris \& Morris 2005, Sang 2008). Using a stakeholder-based approach, we evaluated the human benefits obtained from the Ythan ecosystem and relate these to one another, to biodiversity and to the environment, before analysing the extent to which the current legislative structure relating to the Ythan Estuary accounts for the interactions between the various benefits identified by stakeholders. We used this information to identify (1) the gaps in coverage of existing legislation in terms of components of the ecosystem and perceived human benefits, (2) the advantages and disadvantages that would be likely to result from adapting an Ecosystem Approach to management and (3) the challenges for implementing such an approach. On the basis of this analysis, we make recommendations for the adoption of an Ecosystem Approach to the management of estuarine environments.

\section{MATERIALS AND METHODS}

Participatory workshop. In order to understand how the Ythan Estuary and surrounding Forvie Sands are used and valued by local residents, we held a participatory workshop (18 June 2010) with interested parties from organisations with a stake in managing Forvie, and members of the public who use the area. We invited all members of the Forvie National Nature Reserve (NNR) Panel, a group of stakeholders and user groups who meet regularly to discuss issues that affect the management of Forvie Sands and the Ythan Estuary. The reserve boundary covers Forvie Sands, most of the intertidal and foreshore areas of the Ythan Estuary, and selected areas of the surrounding catchment. Other key stakeholders were identified and invited following a discussion with the organiser of the Forvie Panel. In order to attract members of the public who were not involved with specific organisations, the workshop was also advertised in the main shop in Newburgh, the village adjacent to the Ythan Estuary. Workshop participants included representatives from Scottish Natural Heritage, the Scottish Environment Protection Agency (SEPA), Forvie Panel, the local parish council, as well as local residents. All discussions at the workshop were recorded and transcribed. From these transcripts, we removed dialogue spoken by the workshop leaders (A.H., J.A.G., P.C.L.W., M.S.) before identifying those words used most frequently by the participants using a word cloud generator (Wordle, http:// wordle.net/). The resulting word cloud gives greater visual prominence to words that appear more frequently in the source text, providing an indication of subject matter that is most important to the partici- 
pants. In order to establish meaning and the context in which these words were spoken, we matched the word cloud with the audio recordings of the workshop to ensure that any subsequent interpretation was not misleading.

During the workshop, the participants were asked to discuss how they used the estuary and to list the main benefits it provides. Following definitions in the Millennium Ecosystem Assessment (MA 2005), we categorised these benefits according to whether they were derived from provisioning, supporting, regulating or cultural services. The full list of benefits was summarised, and the participants were asked to illustrate the important uses of the estuary, the interactions between the different components of the estuary, and whether there were any positive or negative factors which influenced these interactions. The resulting diagrams were converted into a single matrix and represented as a benefits network using Netdraw (Analytic Technologies).

Legislation and policy. To understand the diversity of laws and the types of protection they offer to ecosystems, we identified legislation that exists to protect coastal wetlands and considered its scope, extent and the responsible agencies. In addition, we investigated the laws and regulations that apply specifically to the Ythan Estuary to understand how they protect the benefits it provides. The text of national legislation was located using the UK National Archives (www. legislation.gov.uk) and examined to determine the extent to which it included the benefit interactions identified during the stakeholder workshop. We searched the Scottish Natural Heritage archives for text of Forvie NNR byelaws (i.e. laws made by local councils or other bodies, using powers granted by an Act of Parliament) and the Management Statement relating to the SSSI status. All relevant extracts and documents were imported into text analysis software (Nvivo, www.qsrinternational.com/). We adopted the analytical techniques presented by Ekstrom \& Young (2009) to search each of these legislative documents for text relating to the benefit interactions identified by the workshop participants. We did not use an automated algorithm because it was important that we understood the context that the terms were found in, and to replace the terms with others whose meanings were synonymous. Those interactions that were covered were used to build a legislation network using Netdraw (Analytic Technologies).

We compared the benefits and legislation networks to identify any mismatches between the benefits identified by participants and the scope of the legislation. The degree of fit (similarity) between the 2 networks was assessed using a matching metric, $M$, which is the ratio of the sum of the benefit interactions covered by legislation to the total number of benefit interactions (Hanneman \& Riddle 2005, Ekstrom \& Young 2009):

$$
M=\frac{p 11}{(p 11+p 10)}
$$

where $p 11$ is the total number of cells in the legislation-benefits matrix that have a binary value of 11 (interaction recorded in both the benefits and legislation networks), and $p 10$ is the total number of cells in the legislation-benefits matrix that have a binary value of 10 (interaction recorded in the benefits network, but not in the legislation network).

A high value of $M$ indicates a high similarity between the structure of 2 networks, but not the degree to which legislation protects the delivery of benefits. Hence, care was taken to only interpret metric values where we were confident that legislation was protecting the delivery of a benefit, rather than just the components of the system that contributed to a given benefit.

\section{RESULTS}

\section{Benefits}

Workshop participants readily identified 26 benefits which they valued and regarded as being of high importance to communities in and around the Ythan catchment area (Table 1). Of these, recreational services (17 benefits, $65 \%$ ) far outnumbered provisioning (3 benefits, 12\%) and cultural (6 benefits, 23\%) services, whilst supporting services (e.g. primary production, nutrient cycling) were not specifically mentioned. Recreational benefits, such as walking and kayaking, were generally obtained throughout the year, whereas benefits supported by provisioning services, such as fishing and farming, were more seasonal. Some benefits are geographically or temporally restricted (e.g. in designated routes or areas, by licensing, legal restrictions or physical constraints). The cultural/spiritual importance of the estuary was emphasised, especially by participants who had been resident in the area for longer periods of time, as a place of personal significance or as a location where they could go to restore their sense of wellbeing. For these people, there was a strong sense of ownership and belonging. On the whole, stakeholder views reflect immediate benefits rather than those obtained over the longer term. Some benefits are at least partially realised in terms of their direct economic potential, but in most cases the major economic benefits are indirect although they may still make important contributions to human wellbeing.

The word cloud (Fig. 1) and audio recordings confirmed the importance of people and place, but also 
illustrated an awareness of different benefits, such as 'aesthetics', 'recreation' and 'nature' (biodiversity). The use of words such as 'impact' and 'negative' highlighted an awareness of some of the threats to the system and potential conflicts between different user groups.

Workshop participants identified 7 benefit nodes (Fig. 2; 'history and culture', 'food, fish and farming', 'aesthetics', 'education', 'water-based recreation', 'intertidal-based recreation', and 'onshore-based recreation'). In most cases, links between different benefits were mediated through processes. For example, 'onshore recreation' has a negative effect on 'aesthetics' via dog fouling but has a positive effect on 'education' through bird watching. Overall negative interactions $(60 \%$ of total interactions) between these nodes outweighed positive ones, with 'food, fish and farming' and 'intertidal-based recreation' in particular having predominantly negative impacts on other benefits. In contrast, 'education' was identified as having largely positive impacts, whilst, for other benefits, positive and negative interactions were more evenly balanced. Ecological components of the estuary such as birds, seals and sand dunes were clearly seen as positive aspects that enhanced recreation, education and aesthetics.

\section{Legislation}

The relevant legislation is a web of interrelated and overlapping international, European and UK (reserved and devolved) legislation (Fig. 3). The Forvie NNR is affected by the following legislative instruments: the designation as an NNR (National Parks and Access to the Countryside Act 1949 and the Wildlife and Countryside Act 1981); designation of part of the site as a Ramsar site under the Ramsar Convention, Wetlands of International Importance; designation of the Sands of Forvie as a SAC under the Habitats Directive (Council Directive 92/43/EEC on the Conservation of Natural Habitats and Wild Fauna and Flora) and several areas as Special Protection Areas under the Birds Directive (Council Directive 79/4099/EEC on the Conservation of Wild Birds). There is also an SSSI within the NNR (Sands of Forvie and Ythan Estuary SSSI). This was originally designated under the National Parks and Access to the Countryside Act 1949 but is now regulated by the Nature Conservation (Scotland) Act 2004. However, much legislation relates to coastal wetlands, operating at different levels (international, European, national and local) and diverse spatial extents (i.e. land, foreshore, water), with a number of different responsible agencies ensuring that the legislation is enforced (Appendix 1). Numerous pieces of legislation focus on specific components of the ecosystem (particular species, EU Birds Directive 2009/147/EC; habitats,
EU Habitats Directive 92/43/EEC as enacted by the Conservation [Natural Habitats etc.] Regulations 1994). Other legislation is concerned with restricting the impacts of human activity, such as agricultural pollution (EU Nitrates Directive 91/676/EEC). Some legislation covers aesthetics (Countryside Act 1968 and its predecessor, the National Parks and Access to the Countryside Act 1949), and other legislation relates to landscape, recreation, culture and heritage (e.g. National Parks and Access to the Countryside Act 1949 and Nature Conservation [Scotland] Act 2004). More recent legislation (e.g. WFD 2000 and the MSFD 2008) has started to take a more holistic perspective, incorporating the social and economic importance of both the physical and ecological systems.

The Forvie NNR provides an illustration of how these different forms of legislation interact. Forvie NNR is designated under the National Parks and Access to the Countryside Act 1949. Over the 50 yr since that law was passed, the development of law and policy relating to the environment has been increasingly influenced by international and particularly European Law. Furthermore, devolution for Scotland, with the passing of the Scotland Act 1998, gave competence to the Scottish Executive to legislate on most matters relating to the environment. This extremely complicated web of legislation includes remnants of UK legislation, such as the National Parks and Access to the Countryside Act 1949, which has now been partly superseded by both UK legislation and Acts of the Scottish Parliament. The regulation of the area has been augmented by many other pieces of legislation, some emanating from the European Union. An example is the European Habitats and Species Directive 92/43/EC, which was implemented in the UK by the Conservation (Natural Habitats etc.) Regulations 1994 and more recently amended by the Scottish Parliament through the Conservation (Natural Habitats etc.) Amendment (Scotland) Regulations 2007. There is, however, a close relationship with some new legislation reflecting shared powers, duties and responsibilities, such as the Marine and Coastal Access Act 2009 and the Marine (Scotland) Act 2010. The new marine licensing, planning and nature conservation regime is yet to be implemented in full, but there are a number of ongoing policy developments at the UK and Scotland level. The UK Marine Policy Statement, published on 18 March (HM Government 2011), is the framework for preparing Marine Plans and taking decisions affecting the marine environment and was adopted by the Secretary of State and the ministers of the devolved nations. A pre-consultation draft of Scotland's National Marine Plan was also published in March 2011. The requirement to prepare and adopt a National Marine Plan is contained in Part 3 of the Marine (Scotland) Act 2010. The plan must set 
Table 1. (This and facing page) Benefits that stakeholders derive from the Ythan Estuary, the ecosystem service category according to the 2005 Millennium Ecosystem Assessment and the temporal and spatial boundary of the activities. Benefits are listed in no particular order

\begin{tabular}{|c|c|c|c|c|c|c|c|}
\hline & \multirow[t]{2}{*}{ Activity } & \multirow{2}{*}{$\begin{array}{l}\text { Service } \\
\text { category }\end{array}$} & \multicolumn{2}{|l|}{ Economic potential } & \multicolumn{2}{|c|}{ Activity boundary } & \multirow[t]{2}{*}{ Additional remarks } \\
\hline & & & Classification & Realised & Temporal & Spatial & \\
\hline 1 & Walking & Recreation & Indirect & $\mathrm{Y}$ & All year & $\begin{array}{l}\text { Designated } \\
\text { routes }\end{array}$ & \\
\hline 2 & Cycling & Recreation & $\begin{array}{l}\text { Direct, equipment } \\
\text { hire }\end{array}$ & $\mathrm{N}$ & All year & $\begin{array}{l}\text { Designated } \\
\text { routes }\end{array}$ & \\
\hline \multirow{5}{*}{3} & Wildlife watching & \multirow{5}{*}{ Recreation } & \multirow{5}{*}{ Indirect } & \multirow{5}{*}{$\mathrm{Y}$} & & \multirow{5}{*}{ Specific areas } & \\
\hline & $\begin{array}{l}\text { a) Migratory birds, e.g. } \\
\text { geese }\end{array}$ & & & & Seasonal & & \\
\hline & $\begin{array}{l}\text { b) Non-migratory birds, } \\
\text { e.g. eider ducks }\end{array}$ & & & & All year & & \\
\hline & c) Mammals, e.g. seals & & & & Seasonal & & \\
\hline & d) Other, e.g. butterflies & & & & Seasonal & & \\
\hline \multirow[b]{2}{*}{4} & \multirow[b]{2}{*}{ Horse riding } & \multirow[b]{2}{*}{ Recreation } & Indirect & $\mathrm{Y}$ & \multirow[b]{2}{*}{ All year } & \multirow[b]{2}{*}{$\begin{array}{l}\text { Designated } \\
\text { areas }\end{array}$} & \\
\hline & & & $\begin{array}{l}\text { Direct, } \\
\text { trekking/stable } \\
\text { facilities }\end{array}$ & Partly & & & \\
\hline 5 & Dog walking & Recreation & Indirect & $\mathrm{Y}$ & All year & $\begin{array}{l}\text { Designated } \\
\text { routes }\end{array}$ & $\begin{array}{l}6.25 \% \text { of estuary users } \\
\text { are dog walkers }^{\mathrm{a}}\end{array}$ \\
\hline \multirow[b]{2}{*}{6} & \multirow{2}{*}{$\begin{array}{l}\text { Kite surfing and kite } \\
\text { flying }\end{array}$} & \multirow[b]{2}{*}{ Recreation } & Indirect & Y & \multirow[b]{2}{*}{ All year } & \multirow[b]{2}{*}{ Specific areas } & \multirow[b]{2}{*}{ Weather dependent } \\
\hline & & & $\begin{array}{l}\text { Direct, equipment } \\
\text { hire }\end{array}$ & $\mathrm{N}$ & & & \\
\hline 7 & Running / exercise & Recreation & Indirect & $\mathrm{Y}$ & All year & $\begin{array}{l}\text { Designated } \\
\text { routes }\end{array}$ & \\
\hline \multirow[b]{2}{*}{8} & \multirow[b]{2}{*}{ Windsurfing } & \multirow[b]{2}{*}{ Recreation } & Indirect & $\mathrm{Y}$ & \multirow[b]{2}{*}{ All year } & \multirow[b]{2}{*}{ Specific areas } & \multirow[b]{2}{*}{ Weather dependent } \\
\hline & & & $\begin{array}{l}\text { Direct, equipment } \\
\text { hire }\end{array}$ & $\mathrm{N}$ & & & \\
\hline \multirow[b]{2}{*}{9} & & & Indirect & Y & & & \\
\hline & Kayaking / canoeing & Recreation & $\begin{array}{l}\text { Direct, equipment } \\
\text { hire }\end{array}$ & $\mathrm{N}$ & All year & $\begin{array}{l}\text { All } \\
\text { watercourse }\end{array}$ & \\
\hline & & & Indirect & $\mathrm{Y}$ & & & \\
\hline 10 & Metal detecting & Recreation & $\begin{array}{l}\text { Direct, treasure } \\
\text { rewards }\end{array}$ & $\mathrm{Y}$ & All year & All areas & Economic benefits rare \\
\hline & & & Indirect & & & & Restricted to club \\
\hline 11 & Golf & Recreation & $\begin{array}{l}\text { Direct, equipment } \\
\text { hire, clubhouse }\end{array}$ & Y & All year & area & members \\
\hline 12 & Wildfowling & Recreation & $\begin{array}{l}\text { Direct, } \\
\text { accompanying } \\
\text { guide, gun club, bird } \\
\text { management }\end{array}$ & $\mathrm{Y}$ & Seasonal & $\begin{array}{l}\text { Designated } \\
\text { areas }\end{array}$ & $\begin{array}{l}\text { Restricted to those } \\
\text { under licence, quota } \\
\text { system in place }\end{array}$ \\
\hline 13 & Angling & Recreation & $\begin{array}{l}\text { Direct, angling } \\
\text { association, boat } \\
\text { hire, accompanying } \\
\text { guide }\end{array}$ & Y & Seasonal & $\begin{array}{l}\text { All } \\
\text { watercourse }\end{array}$ & $\begin{array}{l}\text { Restricted to those } \\
\text { under licence, quota } \\
\text { system in place. Decline } \\
\text { in fishery reduced } \\
\text { economic benefit }\end{array}$ \\
\hline & & & Indirect & $\mathrm{Y}$ & & & \\
\hline 14 & Art and photography & Recreation & $\begin{array}{l}\text { Direct, tutored } \\
\text { courses }\end{array}$ & Y & All year & All areas & \\
\hline & & & Indirect & $\mathrm{Y}$ & & & \\
\hline 15 & Sailing and power boats & Recreation & $\begin{array}{l}\text { Direct, mooring fees, } \\
\text { vessel maintenance, } \\
\text { launch infrastructure }\end{array}$ & Partly & Seasonal & $\begin{array}{l}\text { All } \\
\text { watercourse }\end{array}$ & $\begin{array}{l}\text { Local deeds prevent } \\
\text { vessel launching }\end{array}$ \\
\hline & Commercial fishing & & & & & & \\
\hline & a) Crustacea, e.g. crabs & & & & & & $\begin{array}{l}\text { Activity historically } \\
\text { important but now }\end{array}$ \\
\hline 16 & b) Fish & Provisioning & $\begin{array}{l}\text { Direct, sale or } \\
\text { produce }\end{array}$ & Partly & Seasonal & Specific areas & reduced largely to \\
\hline & $\begin{array}{l}\text { c) Molluscs, e.g. mussels, } \\
\text { cockles, winkles }\end{array}$ & & & & & & personal usage \\
\hline
\end{tabular}


Table 1 (continued)

\begin{tabular}{|c|c|c|c|c|c|c|c|}
\hline & \multirow[t]{2}{*}{ Activity } & \multirow{2}{*}{$\begin{array}{l}\text { Service } \\
\text { category }\end{array}$} & \multicolumn{2}{|l|}{ Economic potential } & \multicolumn{2}{|c|}{ Activity boundary } & \multirow[t]{2}{*}{ Additional remarks } \\
\hline & & & Classification & Realised & Temporal & Spatial & \\
\hline \multirow{3}{*}{17} & Education & \multirow{3}{*}{ Cultural } & & & \multirow{3}{*}{ All year } & \multirow{3}{*}{ All areas } & \multirow{3}{*}{$\begin{array}{l}\text { Public education centre } \\
\text { and university research } \\
\text { station present }\end{array}$} \\
\hline & $\begin{array}{l}\text { a) Public education and } \\
\text { outreach }\end{array}$ & & Indirect & $\mathrm{Y}$ & & & \\
\hline & b) Schools and university & & $\begin{array}{l}\text { Direct, tutored } \\
\text { courses }\end{array}$ & Partly & & & \\
\hline 18 & $\begin{array}{l}\text { Hotels, public houses } \\
\text { and restaurants }\end{array}$ & $\begin{array}{l}\text { Recreation } \\
\text { and cultural }\end{array}$ & Direct, job creation & $\mathrm{Y}$ & All year & & $\begin{array}{l}\text { Tourism exacerbated } \\
\text { development }\end{array}$ \\
\hline 19 & $\begin{array}{l}\text { Agriculture and } \\
\text { livestock farming }\end{array}$ & Provisioning & $\begin{array}{l}\text { Direct, job creation } \\
\text { and sale of produce }\end{array}$ & $\mathrm{Y}$ & Seasonal & Catchment & $\begin{array}{l}\text { Policy implementation } \\
\text { dramatically changed } \\
\text { type of farming and } \\
\text { farming practices in last } \\
30 \mathrm{yr}^{\mathrm{b}}\end{array}$ \\
\hline 20 & Bait digging & Provisioning & $\begin{array}{l}\text { Indirect, underpins } \\
\text { angling }\end{array}$ & $\mathrm{Y}$ & Seasonal & Specific areas & \\
\hline 21 & $\begin{array}{l}\text { Travelling community } \\
\text { stop point }\end{array}$ & Cultural & $\begin{array}{l}\text { Indirect, cultural } \\
\text { diversity }\end{array}$ & $\mathrm{Y}$ & Seasonal & Specific areas & $\begin{array}{l}\text { Overnight stoppage } \\
\text { prohibited }\end{array}$ \\
\hline 22 & Camping & Recreation & Indirect & $\mathrm{Y}$ & Seasonal & Specific areas & Actively discouraged \\
\hline \multirow[b]{2}{*}{23} & \multirow[b]{2}{*}{ Archaeology } & \multirow[b]{2}{*}{ Cultural } & Indirect & $\mathrm{Y}$ & \multirow[b]{2}{*}{ All year } & \multirow[b]{2}{*}{ Specific areas } & \multirow{2}{*}{$\begin{array}{l}\text { Historical links and } \\
\text { importance in sense of } \\
\text { belonging }\end{array}$} \\
\hline & & & $\begin{array}{l}\text { Direct, tutored } \\
\text { courses }\end{array}$ & $\mathrm{Y}$ & & & \\
\hline \multirow{3}{*}{24} & Housing & & Indirect, & & \multirow{3}{*}{ All year } & \multirow{3}{*}{$\begin{array}{l}\text { Designated } \\
\text { areas }\end{array}$} & \multirow{3}{*}{$\begin{array}{l}\text { Local developmental } \\
\text { plan in place, shore } \\
\text { development desirable }\end{array}$} \\
\hline & $\begin{array}{l}\text { a) Views of estuary and } \\
\text { surroundings }\end{array}$ & Cultural & \multirow{2}{*}{$\begin{array}{l}\text { Direct, property sale } \\
\text { and maintenance }\end{array}$} & $\mathrm{Y}$ & & & \\
\hline & $\begin{array}{l}\text { b) Restricted or no } \\
\text { landscape views }\end{array}$ & & & $\mathrm{Y}$ & & & \\
\hline 25 & Coastal protection & Regulating & Indirect & $\mathrm{Y}$ & All year & Specific areas & $\begin{array}{l}\text { Physical protection from } \\
\text { sand dune (erosion) and } \\
\text { wetland (flooding) } \\
\text { systems }\end{array}$ \\
\hline 26 & $\begin{array}{l}\text { Sense of well being } \\
\text { and/or belonging }\end{array}$ & Cultural & Indirect & $\mathrm{Y}$ & All year & All areas & \\
\hline
\end{tabular}

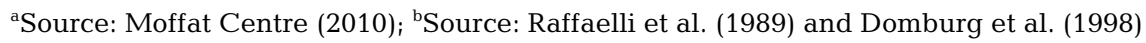

out policies for sustainable development of Scotland's seas and policies on nature conservation, Marine Protected Areas and other relevant conservation sites. Marine Scotland has adopted a 3-tier approach to nature conservation (species conservation, site protection and wider seas policies), which recognises the limitations of traditional nature conservation regulation and includes Environmental Impact Assessment and marine planning. A network of marine conservation sites is also being developed, as required by both the UK Marine legislation and the EU MSFD. Furthermore, the Marine (Scotland) Act 2010 requires the development of regional marine planning and consultation responses on regional marine boundaries. At the time of
Fig. 1. Summary of words $(\mathrm{n}=$ 200) used most frequently by the participants after dialogue spoken by the workshop leaders has been removed. Greater visual prominence is given to words that appear more frequently in the source text, providing an indication of subject matter that was most discussed by the participants

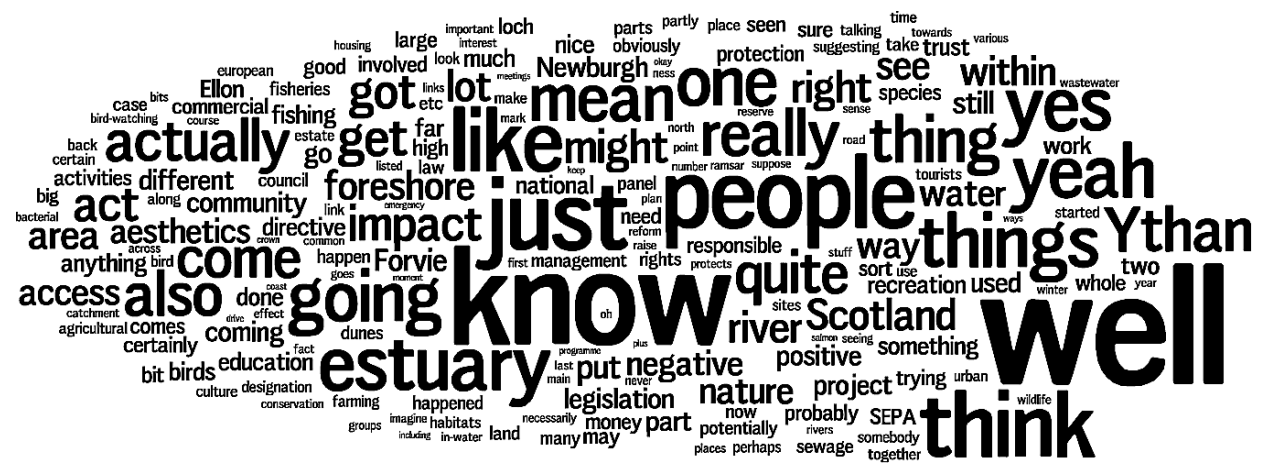


writing, the form of a regional planning regime was being considered by the Scottish Government.

Marine planning and the new instruments to be created under the marine legislation extend from the Mean High Water Spring tide level to 200 nautical miles. The terrestrial planning system extends to the Low Water Spring tide level; there is therefore some limited overlap between marine and terrestrial environments.

\section{Linking benefits to legislation}

Only a small proportion ( $35 \%$ ) of the interactions between the 7 different benefits identified by the workshop participants (Fig. 2) are influenced by environmental legislation, resulting in fewer visible links in Fig. 4. In some cases, only half of an interaction was covered, rather than the complete interaction. For example, the arrow from 'food, fish and farming' $\rightarrow$ 'pollution' $\rightarrow$ 'water recreation' shows that legislation associated with the SSSI Management Statement only protects Forvie NNR against pollution from farming activities, but does not do so for the interests of those that use the area specifically for water recreational activities. This poor match between the benefits and legislation networks was confirmed by a low matching metric ratio $(M=0.068)$. The potential negative impacts of 'food, fish and farming' on other benefits were the most highly regulated, as were various aspects of recreation in relation to the natural environment. There is a relative lack of legislation relating to links to and from 'aesthetics', 'education' and 'history and culture', which is perhaps not surprising given that the Convention for the Safeguarding of Intangible Cultural Heritage (UNESCO 2003) was not ratified by the UK. Most links are covered by a single piece of legislation, although links between recreation and the natural environment are covered by both access-related and nature conservation-related legislation.

\section{DISCUSSION}

Our aims were to understand which benefits generated by a representative coastal system were valued by people and to gain an initial understanding as to

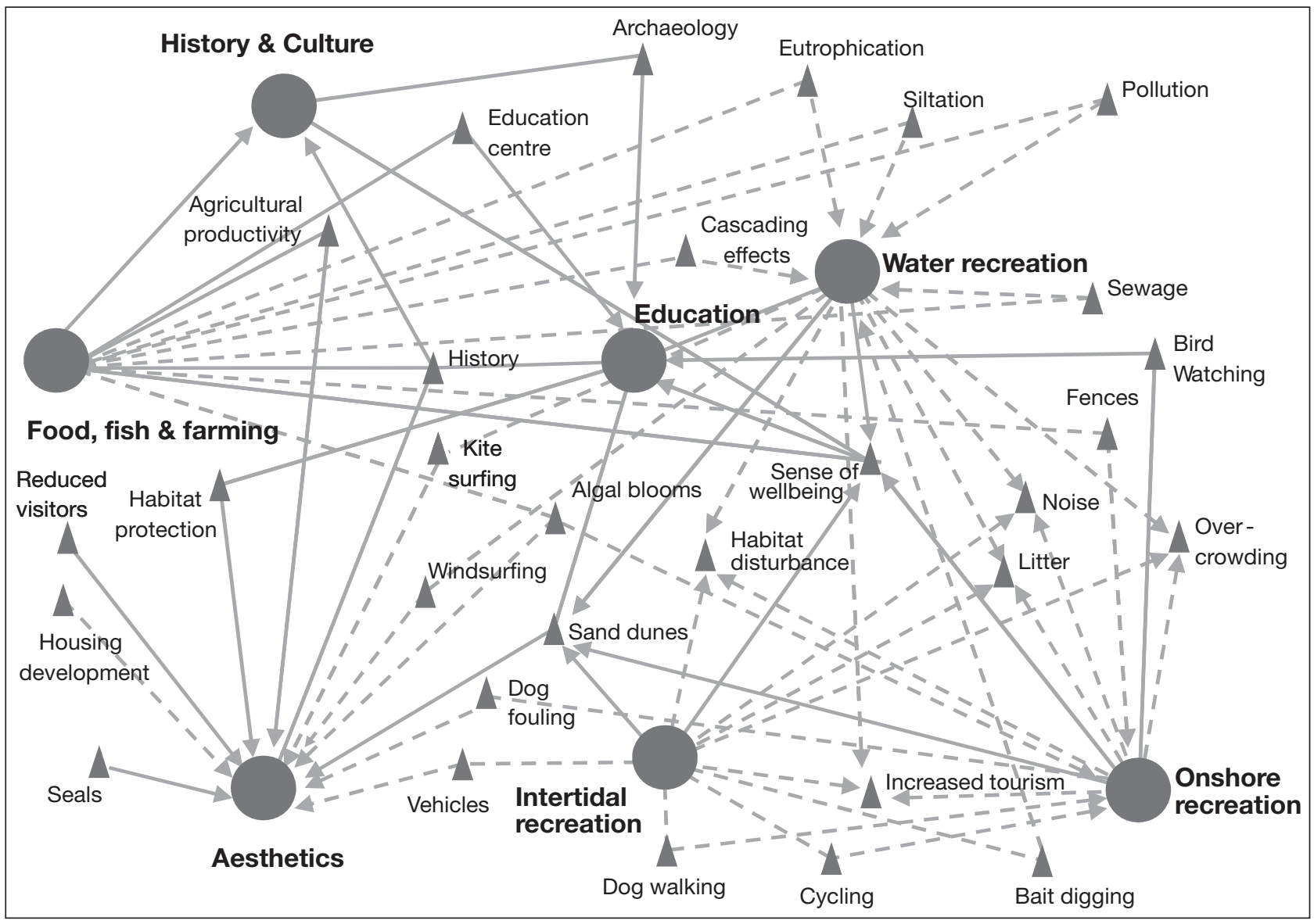

Fig. 2. Benefits that stakeholders derive from the Ythan Estuary (circles), how they interact and what factors (triangles) determine whether these interactions are positive (solid lines) or negative (dashed lines) 
Fig. 3. Relationship between international, European and UK reserved and devolved legislation. International conventions are abbreviated: CCEWNH = The Convention on the Conservation of European Wildlife and Natural Habitats (1979); CCPWCNH = The Convention Concerning the Protection of the World Cultural and Natural Heritage; OSPAR $=$ Convention for the Protection of the Marine Environment of the North East Atlantic; CITES = Convention on International Trade in Endangered Species of Wild Flora and Fauna; RAMSAR = The Convention of Wetlands of International Importance. UNECE = United Nations Economic Commission for $\mathrm{Eu}-$ rope; UNCLOS = United Nations Convention on the Law of the Sea; CBD = Convention on Biological Diversity (Rio Convention)

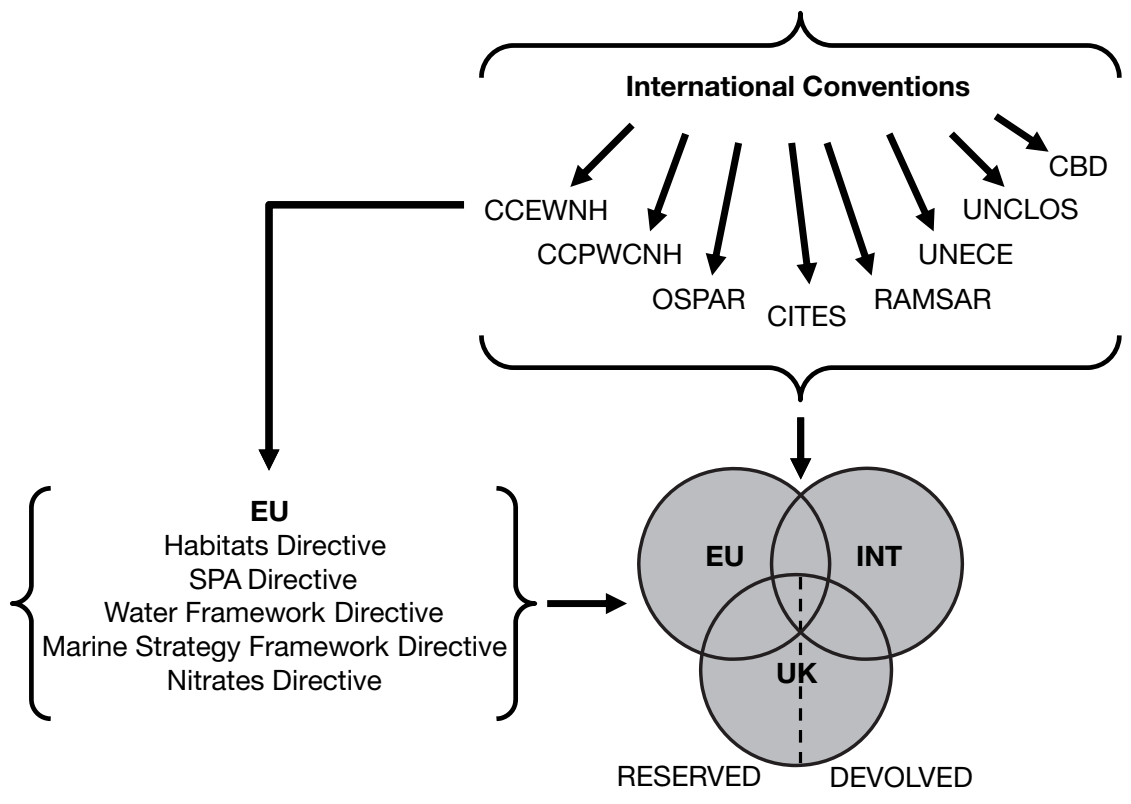

whether legislation had the potential to cover benefit interactions. We found disagreement between the long-term philosophy of the Ecosystem Approach and the perceived needs of the stakeholder community. The latter needs emphasise a requirement for more immediate benefits that were no longer related to extractive natural resources (primarily fish and shellfish) that had been prominent in the past. Many of the benefits valued were recreational activities related to rural living and the enjoyment of the natural environment (Huppert et al. 2003), which are not adequately covered by existing legislation. There are, however, complex interactions between the recreational and cultural benefits that are valued and the consequences of the way that humans manage the land and coast, the latter often having a directional feedback on recreational activities (Wiegand et al. 2010). What is interesting is that many of the activities that were valued are underpinned by wildlife and habitats being intact and free from pollution. For example, much of the aesthetic enjoyment is derived from the natural heritage of the area, the sense of wellbeing that is gained from being in the area, and through activities such as bird watching.

These benefits highlight an understanding of the implications, such as eutrophication and pollution, on certain activities (fishing and farming) and shows that, ultimately, they have an effect on recreational activities. Indeed, increased nitrogen associated with changes in farming practice within the catchment over the last 50 yr (Domburg et al. 1998) has been linked to increased growth in macrophytic algae and, in turn, visible changes to invertebrate and bird population structure within the Ythan Estuary (Raffaelli et al. 1989). Although local stakeholders are acutely aware of these environmental issues, the ability to see agricultural production, including livestock, farm machinery and fields of crops, was nevertheless considered to be important culturally and, to a lesser extent, economically. Similarly, we also found evidence of some interesting recreational benefit feedbacks; stakeholders felt that their enjoyment of the estuary was enhanced by the presence of others, but that too many people would detract from the aesthetics and enjoyment of specific locations. Although not protecting these benefits directly, these examples highlight the important role of conservation legislation in maintaining the quality of what is valued. Consequently, it is possible that these benefit interactions could be covered by certain interpretations of the legislation by the regulating bodies. There is a whole range of legislation that applies to individual nodes of the network that may indirectly protect the benefits of importance to stakeholders. For example, a number of pieces of legislation may protect specific components of the estuary (e.g. seals and birds), but the philosophy of such protection is to preserve the named component rather than its contribution to benefit interactions (e.g. aesthetic significance of birds/seals leading to enjoyment and feeling of wellbeing) that are valued by people. Similarly, legislation that aims to control pollution from human activities, such as farming, may positively impact the recreational value of an area, but does not directly preserve recreational activities. Where the objectives of legislation are restricted to specific and isolated components of the ecosystem, they are of less value to the protection of benefit interactions, as they serve a subtly different purpose.

Although more than one designation may afford a particular location additional protection, or emphasise 
the importance of the site at national and/or international levels (Ross \& Stockdale 1996), it is clear from the analyses here that there is no direct protection for the benefits of value. In order to achieve appropriate protection, an adaptive management and decisionmaking process is necessary that incorporates the views of stakeholders and scientific understanding of linked social-ecological systems. Frameworks that encapsulate these processes have now been described for marine and terrestrial systems (e.g. Daily \& Matson 2008, Turner \& Daily 2008, Daily et al. 2009, Paetzold et al. 2010, Tallis et al. 2010, White et al. 2010), but governance processes need to be in place to allow such frameworks to succeed. There has, however, been a step change in the development of law and policy at a European level (e.g. WFD 2000 and the MSFD 2008), with legislation (Water Environment and Water Services [Scotland] Act 2003, Marine and Coastal Access Act 2009, and the Marine Strategy Regulations 2010) that has the express aim to take a more holistic view of the environment, including the social and economic importance of a resource and/or components of the physico-ecological system. The Marine and Coastal Access Act 2010 even refers to the need to take an Ecosystem Approach, but the manner in which this is implemented ultimately dictates how successful it is likely to be.

Success relies on a network of organisations working together on these issues, with participation from other stakeholders including local groups and users, rather than one responsible agency working in isolation. It also takes time to implement; the first deadline for the

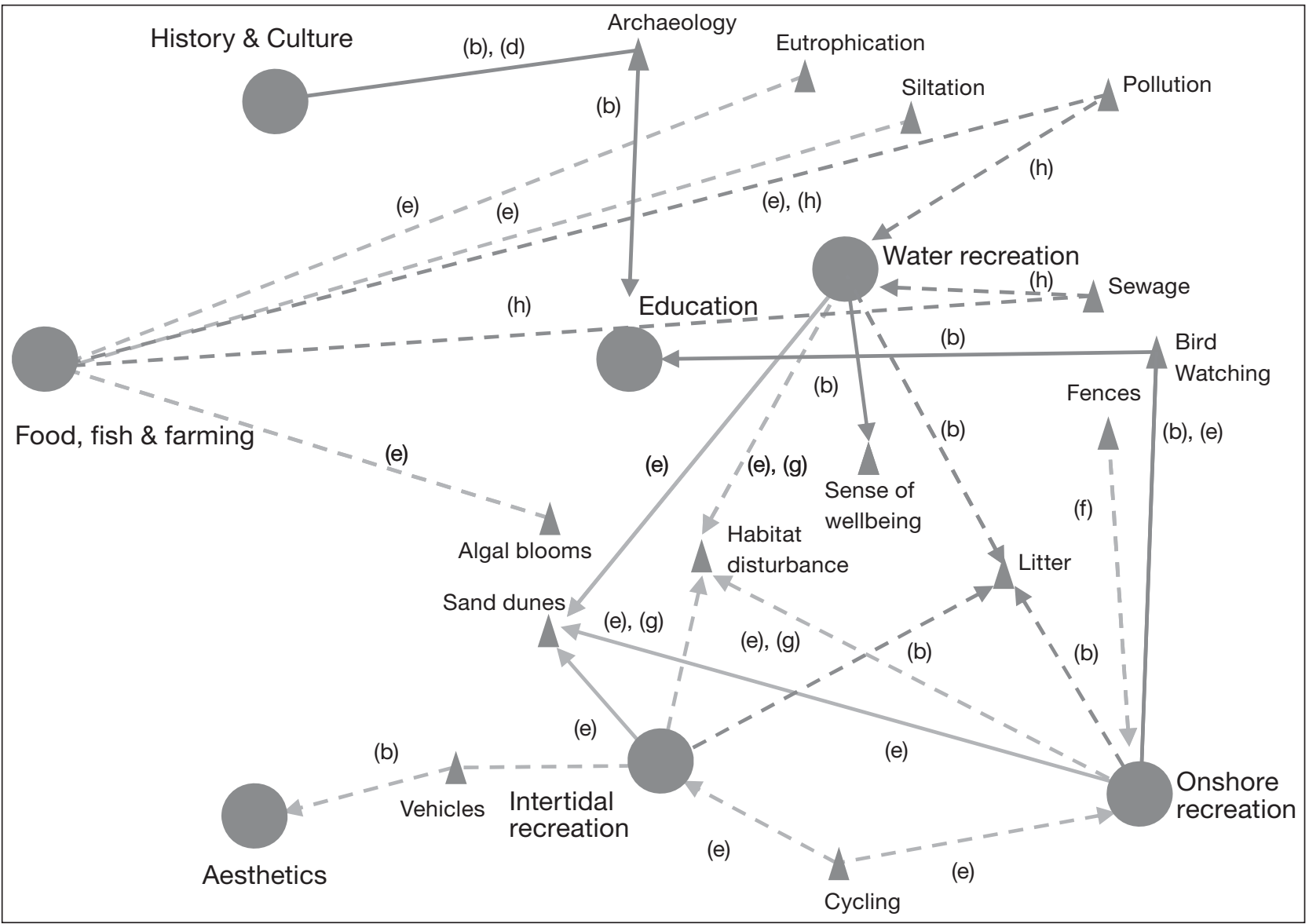

Fig. 4. Benefit interactions from Fig. 2 that are covered by local, national and international environmental legislation. The illustrated network connections are based on the interactions (pairs of terms) noted as important from the stakeholder workshops that appear in the text of legislation relevant to the Ythan Estuary. The letters indicate the legislation which covers the network interactions that appear (the following list includes all legislation searched): (a) Forvie National Nature Reserve (NNR) byelaws, (b) The National Parks and Access to the Countryside Act 1947, (c) The Nature Conservation (Scotland) Act 2004, (d) Natural Heritage (Scotland) Act 1991, (e) Site of Special Scientific Interest (SSSI) Management Statement, (f) Land Reform (Scotland) Act 2003, (g) Conservation (Natural Habitats, etc.) Amendment (Scotland) Regulations 2007 (implementing the Directive on the Conservation of Natural Habitats and of Wild Fauna and Flora 92/43/EEC), (h) Marine (Scotland) Act 2010 (implementing the Marine Strategy Framework Directive 2008/56/EC), (i) Water Environment and Water Service (Scotland) Act 2003 (implementing the Water Framework Directive 2000/60/EC) 
WFD is 2015, but the detailed marine planning and conservation process under the Marine (Scotland) Act 2010 is only at the consultation stage. The Land Use Strategy, for example, acknowledges that the policy framework for management of the marine environment is provided by the marine planning system. Future reviews of the strategy will have regard to marine plans developed under the Marine (Scotland) Act 2010 (p. 6). The future marine plans will therefore physically overlap, albeit limited to the area between high and low tide, with terrestrial plans (Town and Country Planning [Scotland] Act 1997 as amended). Although this will force a merger of marine and terrestrial disciplines (Raffaelli et al. 2005, Reyers et al. 2010), it is considered insufficient to ensure appropriate policy development in relation to both marine nature conservation and the delivery of ecosystem services. None of the legislation appears to protect the functioning of the estuary (e.g. nutrient recycling, carbon sequestration) or the benefits that people value. This is interesting because ecosystem processes and functions are the basis for providing vital and valued ecosystem service benefits and a healthy and biodiverse environment. This omission is largely due to a lack of knowledge of the different levels of functioning required to give rise to certain ecosystem services and benefits, and how the interactions between these processes might affect benefits in both the short and long term. A further complication is that these pieces of legislation can interact (i.e. one level of legislation may be overtaken by another at a different scale) and, as a result, some components of a system may be covered by numerous regulations (e.g. wetland areas could be a Ramsar site, subject to the WFD, or could be a Special Protection Area under the EU Birds Directive, 2009/ 147/EC), whilst others are free from any regulations.

At present, even though a number of responsible agencies are beginning to talk of the importance of adopting the Ecosystem Approach, there is a long way to go before our institutional set up, culture of working and legislation reflects this. Here we have shown how just one aspect of this, the legislation, indirectly protects some important ecosystem processes and benefits by chance rather than by design. On the whole, it seems that the system of legislation is not set up for maintaining benefits that people value, but for protecting specific components of the ecology of coastal wetlands i.e. species and habitats of value, and protecting the ecosystem from the effects of human activity. Whilst this remains important, it is necessary to recognise that the components protected by legislation constitute the prerequisite for anthropogenic activities to take place in aquatic systems, but legislation needs to focus on conserving biodiversity-environment interactions that support what people want or need from the system. The latter is not simple, however, as people value different components of the system, and may not always have the same views; the values of stakeholders affect management, and in turn, these constantly changing opinions of what is important transform the landscape. Such decisions tend to be based on shortterm needs, with little consideration of the long-term implications of actions and changes in the dynamics of the system. Therefore, it is necessary to create management that takes a balance of both the important processes, functions, ecology and benefits.

What is important is that the institutional set up can account for a new way of working - the Ecosystem Approach. This is beginning to be acknowledged through the publication of, for example, A Land Use Strategy for Scotland (2011), which deals with the terrestrial area and the development of a marine planning regime. The intertidal and coastal zone areas are of particular importance in terms of benefit supply and need to be reflected in policy formulation and subsequent legislation. Furthermore, a cross-sector approach (merging across nature conservation, agriculture and inland and coastal water sectors) that works in networks of organisations, rather than as isolated units, is required in order to gain scientific understanding, management and policy expertise, and on-the-ground knowledge and preferences. At present, the implementation of the WFD, the Marine and Coastal Access Act 2009 and the Marine (Scotland) Act 2010 hint at this type of management; however, they remain fragmented as the institutional structures needed for implementation of an Ecosystem Approach do not exist.

To implement an integrated approach, simply coordinating existing institutions, and adding new ones to this arrangement, be they informal or formal, is not likely to yield collaboration. Instead, networks of partnerships between state, public and private stakeholders are more effective for managing social-ecological systems (Olsson et al. 2004, Armitage et al. 2009). These types of arrangements could harness the socialecological knowledge and understanding of local to regional scale user groups, who then participate in the governance process for managing ecosystem services; social networks are thought to play a significant role in achieving these objectives (Folke et al. 2005, Olsson et al. 2008, Bodin \& Crona 2009). In this way, horizontal and vertical linkages connect across scales and facilitate the exchange of knowledge through the wider network. Bridging organisations (as in Berkes 2009) linking a variety of sectors (e.g. nature conservation, water quality and agriculture), rather than centralised authorities, will be key to providing a strategic overview of ecosystem service management at different governance levels (i.e. catchment and basin scales). In 
the UK, it is possible that bodies such as the Marine Management Organisation and its counterpart, Marine Scotland, could fulfil such a role if geographical units, such as a catchment, are used as the basis for integrating management. Such arrangements are thought to be more flexible and resilient, with such institutional diversity an advantage when dealing with uncertainty and multi-scale social-ecological issues (Dietz et al. 2003). Viewing issues as trade-offs between multiple ecosystem services in order to provide multi-functional landscapes brings all sectors into play, increasing institutional diversity and flexibility (Dietz et al. 2003) and will serve to fit governance arrangements with the environmental problems that society is facing.

Acknowledgements. The work was supported by a NERC/ ESRC transdisciplinary research seminar series entitled 'Coastal Wetland Ecosystem Services' (RES 496-26-0040). We thank H. Richardson (University of Sheffield) and C. Thomson (University of Aberdeen) for their assistance with the legislative aspects of the paper. We are very grateful to the participants of the Ythan workshop. Open Access for the Theme Section on Coastal Zone Management is sponsored by Marine Alliance for Science and Technology for Scotland (MASTS) Coastal Zone Joint Research Theme.

\section{LITERATURE CITED}

Armitage DR, Plummer R, Berkes F, Arthur RI and others (2009) Adaptive co-management for social-ecological complexity. Front Ecol Evol 7:95-102

> Atkins JP, Burdon D, Elliott M, Gregory AJ (2011) Management of the marine environment: integrating ecosystem services and societal benefits with the DPSIR framework in a systems approach. Mar Pollut Bull 62:215-226

- Backer H, Leppanen JM, Brusendorff AC, Forsius $\mathrm{K}$ and others (2010) HELCOM Baltic Sea Action Plan-a regional programme of measures for the marine environment based on the Ecosystem Approach. Mar Pollut Bull 60:642-649

Barton J, Pretty J (2010) What is the best dose of nature and green exercise for improving mental health? A multi-study analysis. Environ Sci Technol 44:3947-3955

Basset A (2010) Aquatic science and the water framework directive: a still open challenge towards ecogovernance of aquatic ecosystems. Aquat Conserv 20:245-249

Berkes F (2009) Evolution of co-management: role of knowledge generation, bridging organisations and social learning. J Environ Manag 90:1692-1702

Berkes F (2010) Linkages and multilevel systems for matching governance and ecology: lessons from roving bandits. Bull Mar Sci 86:235-250

Bodin O, Crona BI (2009) The role of social networks in natural resource governance: What relational patterns make a difference? Glob Environ Change 19:366-374

Borja A, Elliott M, Carstensen J, Heiskanen AS, van de Bund W (2010) Marine management-towards an integrated implementation of the European Marine Strategy Framework and the Water Framework Directives. Mar Pollut Bull 60:2175-2186

Daily GC, Matson PA (2008) Ecosystem services: from theory to implementation. Proc Natl Acad Sci USA 105: 9455-9456

Daily GC, Polasky S, Goldstein J, Kareiva PM and others (2009) Ecosystem services in decision-making: time to deliver. Front Ecol Environ 7:21-28

Dasgupta P (2010) Nature's role in sustaining economic development. Philos Trans R Soc Lond B Biol Sci 365:5-11

Dietz T, Ostrom E, Stern P (2003) The struggle to govern the commons. Science 302:1907-1912

> Domburg P, Edwards AC, Sinclair AH, Wright GG, Ferrier RC (1998) Changes in fertilizer and manurial practices during 1960-1990: implications for $\mathrm{N}$ and $\mathrm{P}$ inputs to the Ythan catchment, N.E. Scotland. Nutr Cycl Agroecosyst 52: $19-29$

Ecke F, Hellsten S, Mjelde M, Kuoppala M, Schlacke S (2010) Potential conflicts between environmental legislation and conservation exemplified by aquatic macrophytes. Hydrobiologia 656:107-115

Ekstrom JA, Young OR (2009) Evaluating the functional fit between a set of institutions and an ecosystem. Ecol Soc 14:16

EUR-Lex (2010a) Directive 2000/60/EC of the European Parliament and of the Council of 23 October 2000 establishing a framework for community action in the field of water policy. Available at http://eurlex.europa.eu/LexUriServ/ LexUriServ.do?uri=CELEX:32000L0060:EN:NOT (accessed 25 March 2011)

EUR-Lex (2010b) Directive 2008/56/EC of the European Parliament and of the Council of 17 June 2008 establishing a framework for community action in the field of marine environmental policy (Marine Strategy Framework Directive). Available at http://eurlex.europa.eu/LexUriServ/ LexUriServ.do?uri=CELEX:32008L0056:EN:NOT (accessed 25 March 2011)

Everard M, Jones L, Watts B (2010) Have we neglected the societal importance of sand dunes? An ecosystem services perspective. Aquat Conserv 20:476-487

Folke C, Hahn T, Olsson P, Norberg J (2005) Adaptive governance of social-ecological systems. Annu Rev Environ Resour 30:441-473

Hanneman RA, Riddle M (2005) Introduction to social network methods. University of California, Riverside, CA. Available at: http://faculty.ucr.edu/ hanneman/

Heymans JJ, Howell KL, Ayers M, Burrows MT, Gordon JDM, Jones EG, Neat F (2011) Do we have enough information to apply the Ecosystem Approach to management of deepsea fisheries? An example from the West of Scotland. ICES J Mar Sci 68:265-280

HM Government (2011) UK Marine Policy Statement. The Stationary Office, London. Available at: www.scotland. gov.uk/Topics/marine/seamanagement/international/MPS/ MPSMarch2011

> Huppert DD, Johnson RL, Leahy J, Bell K (2003) Interactions between human communities and estuaries in the Pacific Northwest: trends and implications for management. Estuaries 26:994-1009

> Jennings S, Revill AS (2007) The role of gear technologists in supporting an Ecosystem Approach to fisheries. ICES J Mar Sci 64:1525-1534

> Lloret J (2010) Human health benefits supplied by Mediterranean marine biodiversity. Mar Pollut Bull 60:1640-1646

MA (Millennium Ecosystem Assessment) (2005) Ecosystems and human well-being: current state and trends. Island Press, New York, NY

Moffat Centre (2010) The Natural Heritage as an economic driver: protected areas case studies. Scottish Natural 
Heritage Commissioned Report No. 368 (ROAME No. F05AC701), Scottish Natural Heritage, Inverness

Moran D, Dann S (2008) The economic value of water use: implications for implementing the Water Framework Directive in Scotland. J Environ Manag 87:484-496

Morris CT, Morris RM (2005) The Ythan project: a case study on improving catchment management through community involvement. J Environ Plan Manag 48:413-429

Moss B (2008) The Water Framework Directive: total environment or political compromise? Sci Total Environ 400:32-41

Olsson P, Folke C, Hahn T (2004) Social-ecological transformation for ecosystem management: the development of adaptive co-management of a wetland landscape in southern Sweden. Ecol Soc 9:2

Olsson P, Folke C, Hughes TP (2008) Navigating the transition to ecosystem-based management of the Great Barrier Reef, Australia. Proc Natl Acad Sci USA 105:9489-9494

Paetzold A, Warren PH, Maltby LL (2010) A framework for assessing ecological quality based on ecosystem services. Ecol Complex 7:273-281

Parkes M, Panelli R (2001) Integrating catchment, ecosystems and community health: the value of participatory action research. Ecosyst Health 7:85-106

Raffaelli D (1999) Nutrient enrichment and trophic organisation in an estuarine food web. Acta Oecologica 20:449-461

Raffaelli D, Hull S, Milne H (1989) Long term changes in nutrients, weed mats and shorebirds in an estuarine system. Cah Biol Mar 30:259-270

Raffaelli D, Solan M, Webb TJ (2005) Do marine and terrestrial ecologists do it differently? Mar Ecol Prog Ser 304: 283-289

Reiss H, Greenstreet SPR, Robinson L, Ehrich S, Jorgensen LL, Piet GJ, Wolff WJ (2010) Unsuitability of TAC management within an Ecosystem Approach to fisheries: an ecological perspective. J Sea Res 63:85-92

Reyers B, Roux DJ, O'Farrell PJ (2010) Can ecosystem services lead ecology on a transdisciplinary pathway? Environ Conserv 37:501-511

Ross A, Stockdale A (1996) Multiple environmental designations: a case study of their effectiveness for the Ythan Estuary. Environ Plann C Gov Policy 14:89-100

Sang N (2008) Informing common pool resource problems: a survey of preference for catchment management strategies amongst farmers and the general public in the Ythan river catchment. J Environ Manage 88:1161-1174

Scottish Government (2011a) Getting the best from our land-a land use strategy for Scotland. Available at:
www.scotland.gov.uk/Publications/2011/03/17091927/0

Scottish Government (2011b) Scotland's National Marine Plan, Pre-consultation draft, March 2011. Available at: www.scotland.gov.uk/Publications/2011/03/21114728/0

> Tallis H, Levin PS, Ruckelshaus M, Lester SE, McLeod KL, Fluharty DL, Halpern BS (2010) The many faces of ecosystem-based management: making the process work today in real places. Mar Policy 34:340-348

> Thompson Coon JT, Boddy K, Stein K, Whear R, Barton J, Depledge MH (2011) Does participating in physical activity in outdoor natural environments have a greater effect on physical and mental wellbeing than physical activity indoors? A systematic review. Environ Sci Technol 45: 1761-1772

Tong S, Mather P, Fitzgerald G, McRae D, Verrall K, Walker D (2010) Assessing the vulnerability of eco-environmental health to climate change. Int J Environ Res Public Health 7:546-564

Turner RK, Daily GC (2008) The ecosystem services framework and natural capital conservation. Environ Resour Econ 39:25-35

UK National Ecosystem Assessment (2011) Synthesis of the key findings. UNEP-WCMC, Cambridge

UNESCO (2003) Convention for the safeguarding of the intangible cultural heritage. MISC/2003/CLT/CH/14. Available at http://unesdoc.unesco.org/images/0013/001325/ 132540e.pdf

- Van Hoey G, Borja A, Birchenough S, Buhl-Mortensen L and others (2010) The use of benthic indicators in Europe: from the Water Framework Directive to the Marine Strategy Framework Directive. Mar Pollut Bull 60:2187-2196

Wakefield J (2010) Undermining the Integrated Maritime Policy. Mar Pollut Bull 60:323-333

White PCL, Godbold JA, Solan M, Wiegand JA, Holt AR (2010) Ecosystem services and policy: a review of coastal wetland ecosystem services and an efficiency-based framework for implementing the Ecosystem Approach. In: Hester RE, Harrison RM (eds) Ecosystem services. Issues Environ Sci Technol 30:29-51

Wiegand J, Raffaelli D, Smart JCR, White PCL (2010) Assessment of temporal trends in ecosystem health using an holistic indicator. J Environ Manag 91:1446-1455

> Yaffee SL (1999) Three faces of ecosystem management. Conserv Biol 13:713-725

> Wiegand J, Raffaelli D, Smart JCR, White PCL (2010) Assessment of temporal trends in ecosystem health using an holistic indicator. J Environ Man 91:1446-1455 


\begin{tabular}{|c|c|c|c|c|c|c|c|c|c|}
\hline & 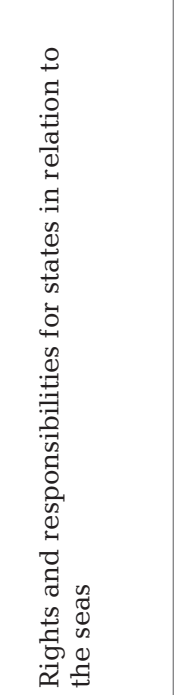 & 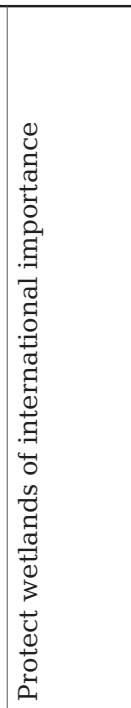 & 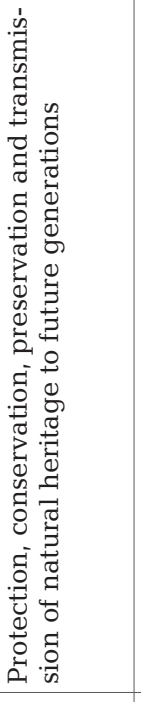 & 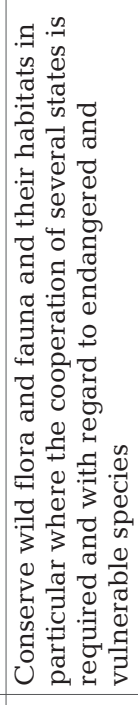 & 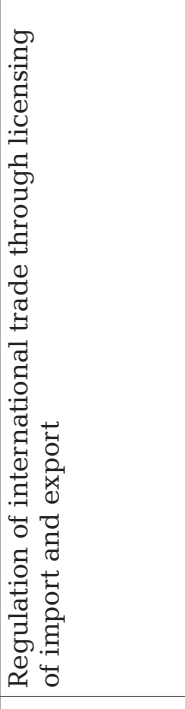 & 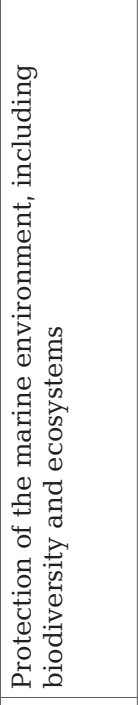 & 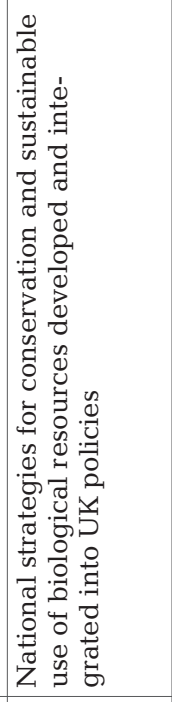 & 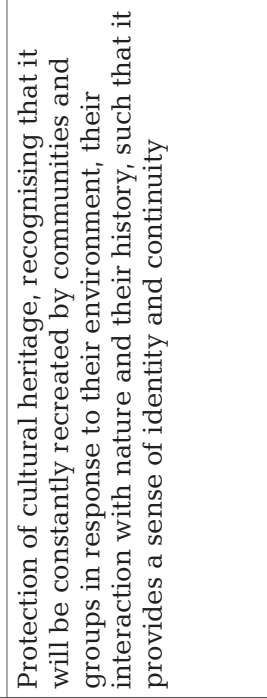 \\
\hline 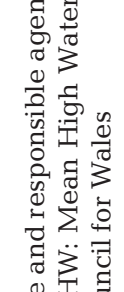 & 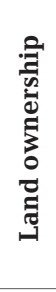 & 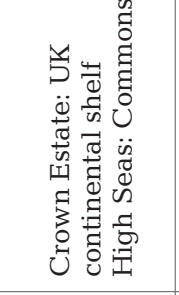 & 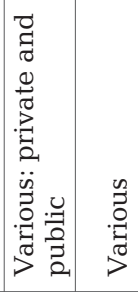 & 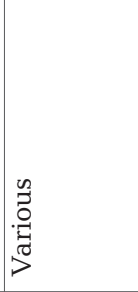 & 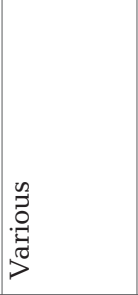 & 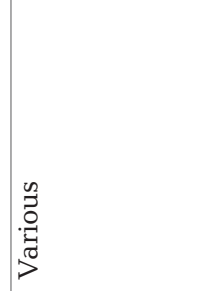 & 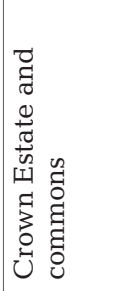 & 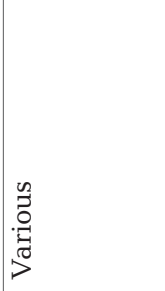 & 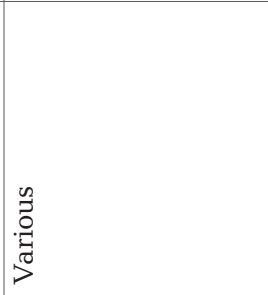 \\
\hline 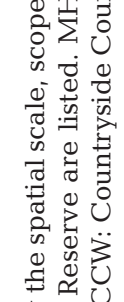 & 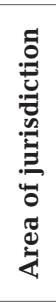 & 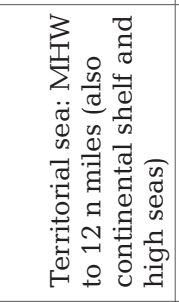 & 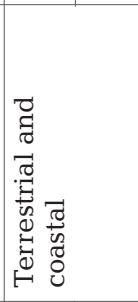 & 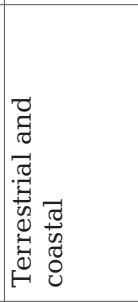 & 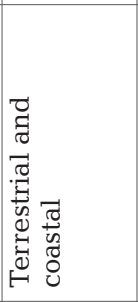 & 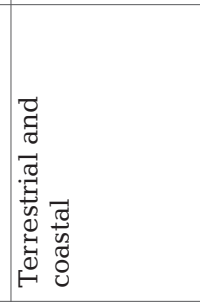 & 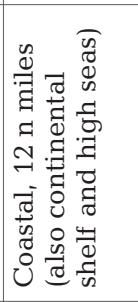 & 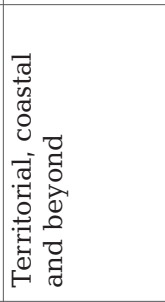 & 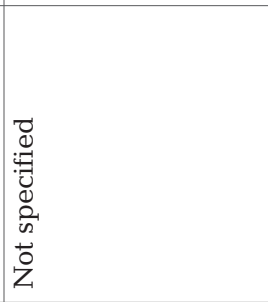 \\
\hline 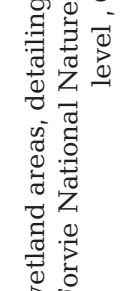 & 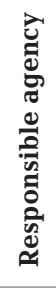 & 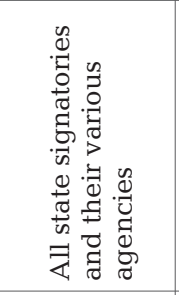 & 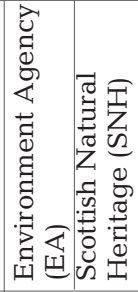 & 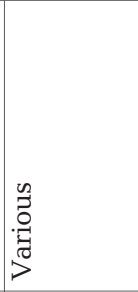 & 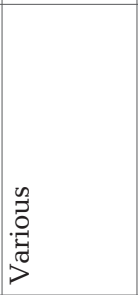 & 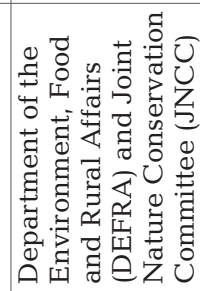 & 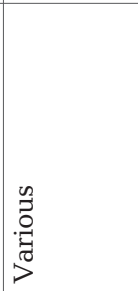 & 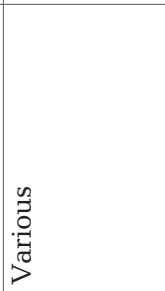 & 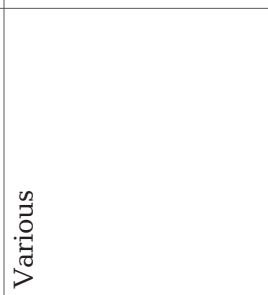 \\
\hline 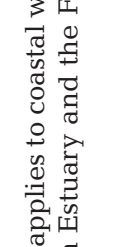 & 莒 & 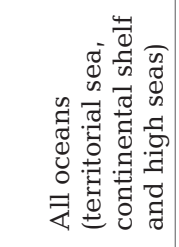 & 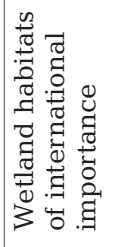 & 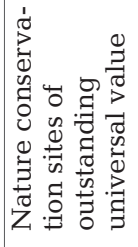 & 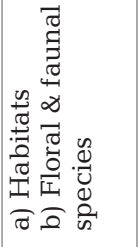 & 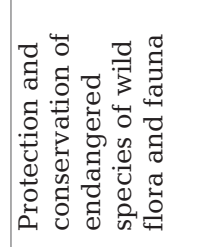 & 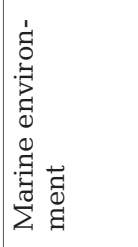 & 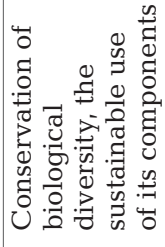 & 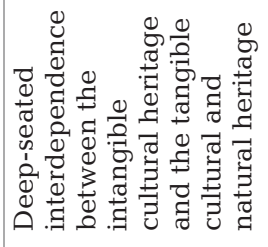 \\
\hline 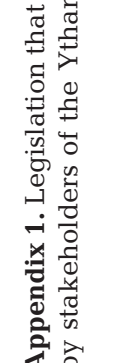 & 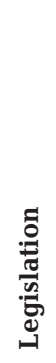 & 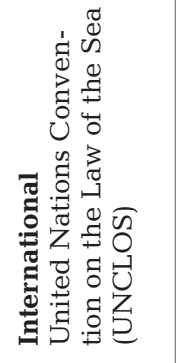 & 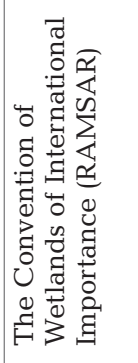 & 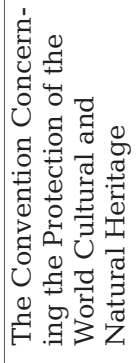 & 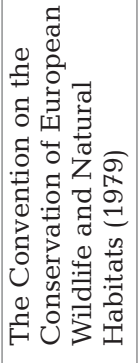 & 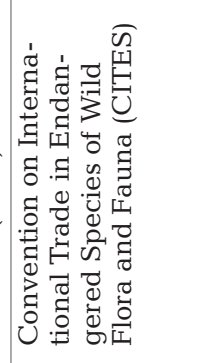 & 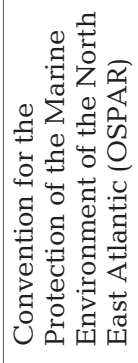 & 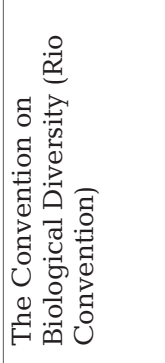 & 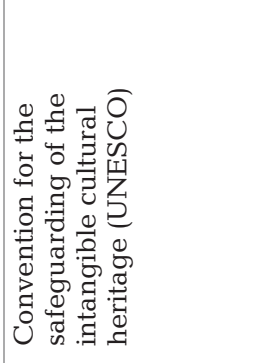 \\
\hline
\end{tabular}




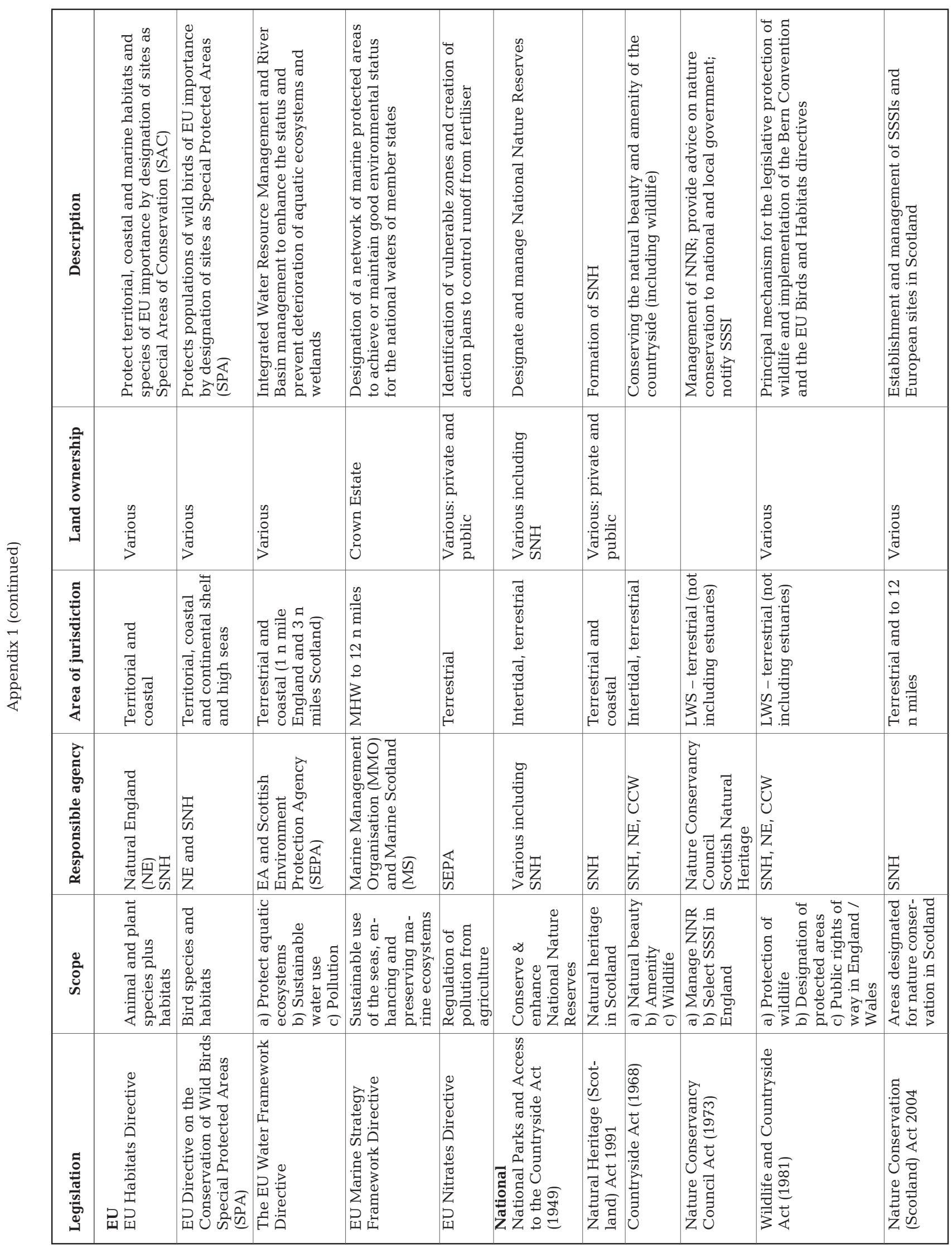




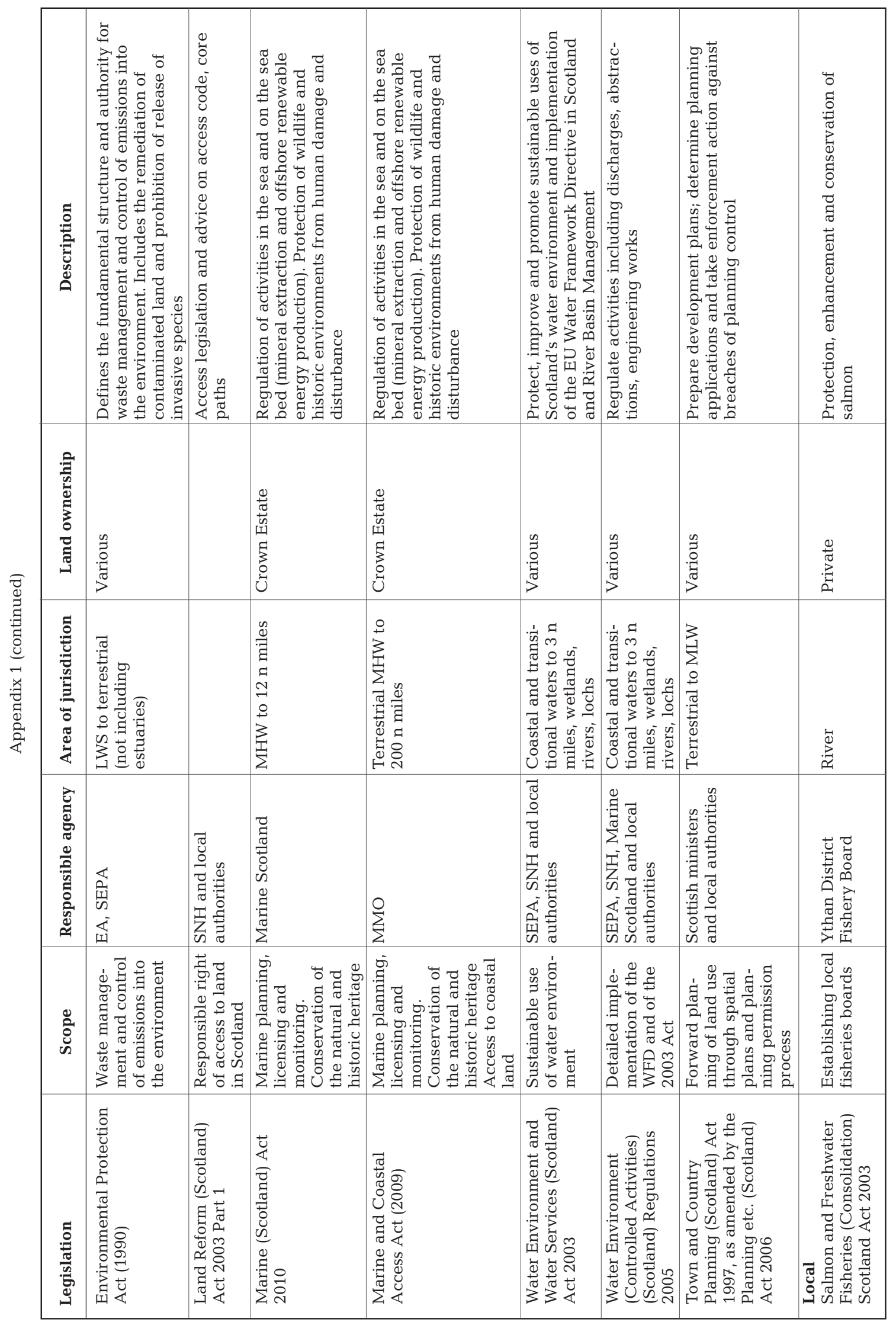

